\title{
ETHNOLOGICAL IDEAS AND APPROACHES IN BULGARIAN FOLKLORE STUDIES
}

\section{VALENTINA GANEVA-RAYCHEVA}

This paper presents the trend in Bulgarian folklore studies being developed at the Institute of Folklore at the Bulgarian Academy of Sciences, ${ }^{1}$ in ethnology, ethnological and anthropological approaches, and research problems. Special attention is paid to the role played by the institute's scholars in institutionalizing ethnology in schools of higher education and training specialists (MA and PhD students) in ethnology in the last twenty years.

Keywords: folklore studies, ethnology, cultural identity, local cultures, communities and culture, cultural heritage.
Članek predstavlja usmeritev bolgarske folkloristike, kakor se je razvila na Institutu za folkloro Bolgarske akademije znanosti, $v$ etnologiji, etnoloskih in antropoloskih pristopih ter raziskovalnih problemov. Posebna pozornost je namenjena vlogi institutskih raziskovalcev pri institucionalizaciji etnologije $v$ visokem izobraževanju in usposabljanju specialistov (magistrskih in doktorskih študentov) $v$ zadnjih dvajsetih letih.

Ključne besede: folkloristika, etnologija, kulturna identiteta, lokalne kulture, skupnosti in kultura, kulturna dedišcina.

Today there is probably no discipline that is not going through an identity crisis. Scholarly tendencies in recent years have discussed the borders between disciplines, opening new "borderline" spheres of research. Social and political realities have led to reassessment of the reflexivity of the social sciences and the humanities, and reassessment and redefinition of their purview. The twentieth century created disciplines such as the ethnography of speech, empirical cultural studies, ethnic poetics, ethnic psychosociolinguistics, cultural ecology, ethnosociology, ethnomethodology, reflextive anthropology, shared anthropology, urgent anthropology, anthropology at home, and sociological ethnography. Old theories were renewed, and the biographical approach and discursive analysis were extensively applied. This scholarly palette and methodological polyphony outlines how significant the diversity of approaches to studying the human being is and how synthesis founds and forms the idea of the "synthetic knowledge of humankind" (Todor Zhivkov).

1 As a result of restructuring the Bulgarian Academy of Sciences after 1 July 2010, the Institute of Folklore is united with the Ethnographic Institute and Museum under the name Institute of Ethnology and Folklore Studies and Ethnographic Museum. This text does not comment on how ethnography is developing towards ethnology. 
In Bulgarian scholarship, ethnology was not institutionalized into a separate discipline until the 1990s. Significant credit for the fact that ethnology acquired an independent existence as a research and teaching discipline in schools of higher education belongs to Bulgarian folklore studies, and especially to the folklore specialist Todor Zhivkov. Why did folklore studies undergo such a change? Why was this possible in the 1990s?

During the 1970s, folklore studies in Bulgaria extended beyond the framework of the philological interpretation of folklore and turned into a leading school in the national humanities during the last three decades of the century. Folklore was viewed as a type of cultural system, a complex unity of cultural activities and combination of cultural values that are established unconsciously and transferred across time as inherited cultural information. Folk culture is interpreted as intermediate between the individual and group mind, between the ethnic and interethnic, between the aesthetic and non-aesthetic, between the everyday and holidays, between the sacred and profane, and so on. Structural, genetic, and regional aspects of folk texts have been interpreted. Folklore continues to be interpreted as a type of thinking, expression, communication, and self-realization-and as a human cultural necessity in the twenty-first century as well.

Since 1989, when the democratic changes took place, social studies and the humanities in Bulgaria tried to respond to the intensive interest in "others" and understanding their worlds. Folklore studies offered its experience in identifying "us" and "them" in culture, from the family to the ethnos, by interpreting the entire process of involving the individual within the network of communities through adoption and transfer of cultural values. It offered the theoretical minimum and empirical foundation for further study of the interaction processes between the individual and community, community and culture, traditional and modern, and different types of culture (see Bochkov 1998).

At the beginning of the 1990s, Zhivkov presented and proved his concept of ethnology in Bulgaria; that is, he laid the foundations of the Bulgarian ethnologic paradigm. His interest in ethnology dates from the 1980s (Zhivkov 1979, 1979a, 1985, 1987). In his studies from that time, the scholar interprets folklore as a specific reflection of the life of the ethnos, the ethnic memory, and a means to form ethnic identity.

Together with a team of university lecturers and scholars from various institutes of the Bulgarian Academy of Sciences (mainly from the Institute of Folklore) Zhivkov accomplished his program to introduce ethnology in schools of higher education (Zhivkov 1994). The first ethnology students were accepted during the 1990/1991 academic year. The program was carried out at Paisiy Hilendarsky University in Plovdiv and Southwest Neofit Rilsky University, based on philological knowledge and closely related to social studies. During the 1997/1998 academic year, again under the leadership of Zhivkov in Sofia, a program in ethnology started at the Faculty of Philosophy 
and Social Studies. At all three universities, this scholar implemented his idea for integral education. The ethnological disciplines are balanced such that they introduce systematic linguistic, sociological, philosophical, psychological, historical, and cultural aspects (Ganeva-Raycheva 1997).

The first publications also started appearing, addressing the theoretical basis of ethnology and its teaching in schools of higher education, written by scholars from the Institute of Folklore (Zhivkov 1994, 2000; The Folk Culture 2002; Communities 2003). In the journal Balgarski folklor the "Alma Mater" section started publishing studies in various ethnologic disciplines. In the 1990s at St. Climent Ochridsky University in Sofia, a Center in Ethnology was founded and later a course in ethnology started being offered at the Faculty of History. Its curriculum at least during the initial years was founded on the courses in ethnology offered in "The Ethnic Syndrome." Again in the 1990s, anthropological studies started at the New Bulgarian University, where disciples of Zhivkov were already lecturing.

Zhivkov developed his views on ethnological knowledge applying the experience of foreign anthropology and ethnology and the research and achievements of Bulgarian folklore studies. As he himself claims, his knowledge of folk culture is the "massive resource" where ethnology starts (Zhivkov 2000: 8). The development of French and Anglo-American research traditions, which are characterized by the terms ethnology, cultural anthropology, and social anthropology, outlines the common research interests and subjects of study, similar methods, and methodologies over the years. According to Zhivkov, their arbitrary differentiation could be achieved only in the following way. Ethnology offers a typology of communities; it recognizes and interprets the cultural diversity through which these communities construct their identity. Anthropology recreates all the paths of man in the accumulation of social and cultural experience through his participation in various networks; it outlines the relations between the social and its interpretations in culture (e.g., the behavior rules and their symbolism).

Zhivkov's thesis that ethnology is synthetic knowledge about human communities extends beyond the limits of specialized scholarly knowledge about the ethnos and its culture, and it reveals a perspective in which the interest is directed not so much towards the past and history, but to outlining the contemporary events and processes going on in various communities, including ethnic ones. The scholar reconsiders his knowledge of human communities by studying man and society with a view on everyday life and the objective phenomena of cultural activities: language, mythology, folklore, customs, rituals, and so on. Ethnological knowledge also includes the three dimensions of human existence: the semiotic view, normative view, and technological view. In spite of the society they exist in (traditional, modern, or post-modern), the communities have their own "grammar," their own time and space, and their identity, behind which exist systems studies by ethnology family systems, technological systems, 
and symbolic systems (languages, mythology, traditions, clothing, cuisine, etc.). These ideas acquire more detailed and more general scholarly interpretation in the book "Introduction to Ethnology." Mention should also be made of "Ethnological Perspectives of Man," in which social characters are presented, "The Wheel of Life," in which the semiotics of childhood, adultery, old age, and death are presented, "Approaches to Human Communities," discussing issues in the ethnology of space, kinship, family, and ethnos, with special attention on the Balkan ethno-cultural thesaurus and interethnic interactions, and "Issues of the Ethnosphere," presenting a new and original perspective on the problem of the ethnic. In his analyses the scholar persistently implements three principles: the genetic, typological, and areal principles.

Zhivkov insists that the power of Bulgarian ethnology lies in its attempts to interpret our own society, in studying the cultural facts in their social and political context. Ethnological knowledge is attained not only through science but also through art and religion. This makes ethnology a constituent component of culture itself, one means of its development and assessment. The scholar gives evidence of two forms of ethnological knowledge. The first one is the general theory of ethnology and the second is offered by various disciplines through their ethnological competence (Zhivkov 2000). In this respect he emphasizes the close interrelation of ethnology with linguistics, its stronghold in language, and systems of symbols; he draws attention to the anthropological and ethnological competence of social studies, psychology, philosophy, history, and so on.

At the beginning of the 1990s at the Institute of Folklore, Zhivkov began a seminar on the anthropology of folklore. This was the result of the desire to change perspectives, as well as to apply different perspectives to folklore as a cultural universal. The development of these ideas was presented in a series of issues of the journal Balgarski folklor (1994, no. 2; 1995, nos. 3 and 4). The seminar discussions served as a significant form of epistemological and methodological research as well as for clarifying current cultural processes and phenomena. The seminars he carried out include "Heritage and Dialogue between Cultures," "The City in Transition," "Forms of Civic Participation," "Culture as a Local Development Resource," "Visual Anthropology," and "Ideas and Fields in Anthropology." General and specific issues in folklore, ethnology, and anthropology are considered together with the history of these disciplines and their relations with other disciplines. The ideas developed are covered in thematic issues of the journal Balgarski folklor and in electronic publications (www.itefa.dir.bg).

The main emphases of the research carried out at the Institute of Folklore in recent years are related to issues of cultural identity and intercultural interactions in the Bulgarian and European context, modern cultural policies, and theoretical and applied aspects of intangible cultural heritage. The aim is to apply an interdisciplinary approach to these issues (using the methods of folklore studies, cultural anthropology, ethnology, ethnomusicology, sociology, etc.). 
From 2004 to 2009 at the Institute of Folklore, forty international projects were developed, accomplished within the European Economic Interest Group or through funding from foundations and programs of the European Union. They focus on theoretical and methodological problems, cultural traditions, cultural heritage, and ethnocultural interactions from a Balkan and European perspective. The findings of the studies are presented in volumes and bilingual editions. One example is the collected volume Bulgaria-Italy: Debates, Local Cultures, Traditions, a result of the BulgarianItalian project Cultural and Political Ideas about Western Europe and the Balkans: Historic and Anthropological Discourse. In their studies, the Bulgarian and Italian scholars present theoretical debates on the concepts of folk culture, folklore, and heritage. Significant problems of constructing and managing regional and local heritage are considered, and the archival and museum policies for legitimizing heritage. Special attention is paid to the role of traditions and cultural institutions to constitute local and national identity (Santova and Pavanelo 2006).

Another emphasis in the institute's work is studies of the cultural identity of Bulgarian communities abroad (in Hungary, Slovakia, the Czech Republic, Poland, Moldova, Romania, Serbia, Austria, and Macedonia). The theoretical foundation of assessing emigrant lives is the constructive approache to identity and cultural heritage. Strategies are analyzed for individual and community identification in life abroad, transfer of and sharing cultural patterns in the host society, instances of cultural bilingualism, intercultural interactions, activities of the émigré cultural institutions related to preserving and maintaining Bulgarian cultural identity and the recognition of the Bulgarians in the host society, forms of cultural exchange between the country of origin and the host country, and so on (see Penchev 2001; Ganeva-Raycheva 2004a; Penchev and Rashkova 2005; Penchev and Krekovichova 2006).

A significant place in the institute's activities is held by studies of the cultural specifics of ethnic and religious communities in Bulgaria and abroad. The interest is oriented toward artifacts, but also toward contemporary cultural practices and policies of identity. Some of the studies outline and present forms of coexistence and cultural exchange between communities and groups of various kinds. The processes of constructing local heritage and how it functions are studied, as well as behavioral patterns of the communities in daily life and on holidays and within the context of state policy. The interest is oriented towards ethnic and religious communities that have been present for many years in Bulgarian ethnic territory and the visible presence of Armenians, Jews, Roma, Turks, Vlachs, Armani, and Gagauzi in Bulgarian society, as well as religious minorities such as Bulgarian Catholics and Bulgarian Muslims, and, less conspicuously, groups such as Slovaks, heterodox Muslims, and Old Believers.

Within the context of regional cultures, various local, ethnic, and regional communities are studied that have inhabited and now inhabit Bulgarian ethnic territory. 
The issues of their identity and the processes of inheriting cultural values and traditions are interpreted according to verbal, musical, plastic, dance, and ritual cultural forms, through analyses of cult architecture, and through various methods and approaches (Santova and Stanoeva 2002; Mikov 2006).

This issues in this area, the change of perspective, and the approaches are presented in the following dissertations: Visual and Anthropological Characteristics of Contemporary Bulgarian Graffiti (M. Ivanova), Festivity Traditions and Political Practices (P. Petrov), Formation of Jewish Identity in Bulgaria after 1989 (Y. Dadova), The City and the Mine: Constructing Urban Space, The Example of Pernik from 1880 to 1945 (Z. Stoyanova), "Folk History" between the Oral and the Written (Ts. Dimitrova), Visual Markers of Memory in Urban Space: On Materials from the City of Ruse (Sv. Toncheva), Ethnic Stereotypes in Everyday Culture (L. Gergova), New Religious Movements in Europe (Sv. Toncheva), and others.

In recent years, the Institute of Folklore has carried out applied projects in culture, transmission of cultural experience, and the use of culture (including intangible cultural heritage) as a resource for urban and rural development. The following should be mentioned in particular:

- The City: Identification Processes and Social Transformations (2003-2005, funded by the Open Society Foundation), based on research in ten Bulgarian cities, with application in social policies and preserving cultural heritage, with a large research team comprised of scholars from the Institute of Folklore, university lecturers, and doctoral students;

- Documentation and Preservation of Folklore: The Cultural Life of Disabled People in Bulgaria (2004, funded by the Donation Program of Ford Motor Company Bulgaria). This is the first folklore and ethnology study of its kind of communities of people with unequal status in Bulgaria, in collaboration with the Union of the Blind in Bulgaria;

- New Alternatives of Livelihood in the Municipality of Garmen (Bulgaria) and Bossilovo (Macedonia) through Transborder Collaboration for the Development of Stable Tourism (2007, funded by the funds of the European Union), This is a successful step in including scholars from the institute in the activities of some settlements in Bulgaria to develop cultural products and cultural tourism.

Another aspect that I would like to present is the participation of scholars from the Institute of Folklore in training specialists in ethnology and anthropology.

In the doctoral school at the Center of Education at the Bulgarian Academy of Sciences, specialists from the institute take part in training doctoral students in the humanities and social sciences as lecturers in courses related to lifecycle and culture, cultural and social transformations in the city, cultural heritage, ethnicity and nationalisms in the contemporary world, methods of ethnological research, and so on. 
Scholars from the institute take part in training ethnologists and anthropologists in the bachelor's and master's programs in ethnology and anthropology at the Paisiy Hilendarsky University in Plovdiv, Southwest Neofit Rilsky University, St. Climent Ochridsky University in Sofia, and the New Bulgarian University. I would specifically mention the Bulgarian-Italian master's program "Anthropological Studies of the Mediterranean and the Balkans: Italy-Bulgaria," cooperation between the Institute of Folklore, La Sapienza University in Rome, and the Faculty of Classical and New Philologies at the Department of Roman Studies at St. Climent Ochridsky University in Sofia on a topic that started during the 2006/2007 academic year. Scholars from the institute teach the following classes within this program Folklore (St. Boyadzhieva), Anthropology of the Village (D. Dobreva), Anthropology of the City (M. Santova), Musical Anthropology (R. Neykova), Field Research in Anthropology (V. Ganeva-Raycheva), and Nations and Nationalism: Minorities, Transnational Communities, Transnational Affiliation (E. Anastassova).

Contemporary social, cultural, and political reality raises new challenges for the social sciences and humanities connected with transcending the borders between disciplines, creating interdisciplinary partnerships, and reformulating or expanding research skills. The development of training in anthropology and ethnology, and the achievements of young scholars require efforts by Bulgarian scholars to change the existing patterns in disciplines, professions, and branches of research, which at present hamper the disciplines and force specialists to argue for some borders that do not exist.

To conclude, the changes in the development of Bulgarian Folklore Studies can be outlined as follows: a change of perspective towards the subjects studied (combining micro- and macro-analyses at various levels), seeking new subjects, and an interdisciplinary character of studies. After 1990, the scholarly perspective in Bulgaria was permanently directed toward the city and urban ethnology and anthropology. Some issues of interest are the role of urban institutions in training and transmitting folklore, transforming forms of regional folk culture in urban heritage, applications of folklore in creating a national narrative, and, currently, the image of Bulgaria as a culturally diverse country that is part of European cultural space. The institute contributes to studying the traditional and contemporary cultures of communities of various kinds: local, regional, national, transnational, ethnic, religious, and so on. Subjects of interest include juvenile subcultures and cultures of groups with unequal social status. Folklore studies successfully interpret the subcultural phenomena and processes in the contemporary world in music, rituals, and verbal works. Decisive steps are also being made in applied ethnology. 


\section{REFERENCES}

Алексиев, БожиАар [Aleksiev, Bozhidar]

2005 Фолклорни профили на мюсюлмански светщи в България. София: АИ „М. Аринов”. [Folklore Profiles of Muslim Saints in Bulgaria. Sofia: Academic Publishing House "M. Drinov".]

Alexiev, Bozhidar et al.

2007 Regions, Minorities and European policies: A state of the art report on Muslim Minorities (Turks and Pomaks) In Central South Planning Region (Bulgaria). IMIR. (http://www.imir-bg.org/imir/ reports/Bul-state\%20of\%20the\%20art\%20report-final.pdf).

2007a Regions, minorities and European integration: A case study on Muslim minorities (Turks and Muslim Bulgarians) in the SCR of Bulgaria. IMIR. (www.imir-bg.org/imir/reports/Bulgaria_Muslims_ case_study_FINAL-ed.pdf).

Анастасова, Екатерина [Anastasova, Ekaterina]

1998 Старообредиите в България. - мит, история, идентичност. София: АИ, „Проф. Марин Аринов. [The Old-Believers in Bulgaria - Myth, History, Identity. Sofia: Academic Publishing House "M. Drinov".]

2006 Етничност, традиция, власт. Етюди за прехода. София: АИ „М. Аринов”. [Ethnicity, Tradition, Power: Etudes on the Transition. Sofia: Academic Publishing House "M. Drinov".]

Бочков, Пкамен [Bochkov, Plamen]

1998 Фолклористични аспекти на етноложкото познание. Български фолклор 24 (1-2): 150-158. [Folkloristic Aspects of Ethnological Knowledge. Bulgarian Folklore 24 (1-2): 150-158.]

2006 Етнология и антропология в Бъцгария: в тьрсене на нова парадигма. В: България - Италия. Аебати, локални култури, традичии. София: АИ „Проф. Марин Аринов”, 19-25. [Ethnology and Anthropology in Bulgaria: Looking for a New Paradigm. In: Bulgaria - Italy: Debates, Local Cultures, Traditions. Sofia: Academic Publishing House "M. Drinov", 19-25.]

Ганева-Райчева, Валентина [Ganeva-Raycheva, Valentina]

1997 Пет години университетска етнология. Български фолклор 23 (3-4): 144-151. [Five Years University Ethnology. Bulgarian Folklore 23 (3-4): 144-151.]

2000 Тодор Ив. Живков. Увод в етнологията. Пцовдив, Изд. на ПУ „Паисий Хилендарски”, 2000. Български Фолклор 26 (4): 115-117. [Todor Iv. Zhivkov, Introduction to Ethnology. Plovdiv; Publishing House of PU "Paisiy Hilendarsky", 2000. Bulgarian Folklore 26 (4): 115-117.]

2004 Разказване и идентичност. София: ИК „Яр” [Narration and Identity. Sofia: Yar Publishing House].

2004 Българите в Унгария - проблеми на културната идентичност. София: АИ „Марин Аринов” [Bulgarians in Hungary - Problems of Cultural Identity. Sofia: AI "Marin Drinov.]

Живков, Тодор Ив. [Zhivkov, Todor Ivanov]

1979 Етнически аспекти на фолклора. Аитературна мисыл (София) 4. [Ethnic Aspects of Folklore. Literaturna Misal (Sofia) 4.]

1979а Някои етнолингвистични аспекти на фолклора. В: Фолклор, език и народна съдба. София: АИ „Проф. Марин Аринов”. [Some Ethnolinguistic Aspects of Folklore. In: Folklore, Language, Destiny. Sofia: Academic Publishing House "M. Drinov".]

1985 Етносьт (Опит за социологическа характеристика). Сочиологически проблеми (София): 6081. [The Ethnos: An Attempt at Sociological Characteristic. Sociological Problems (Sofia), 60-81.]

1987 Eтнокултурно единство и фолклор. София: Издателство „Наука и изкуство”. [Ethnocultural Unity and Folklore. Sofia: Nauka i izkustvo Publishing House.]

1994 Етничният синдром. София: ИК „А^я”. [The Ethnical Syndrome. Sofia: Alya Publishing House.]

2000 Увод в етнологията. ПАовдив: ПАовдивско университетско издателство. [Introduction to Ethnology. Plovdiv: Plovdiv University Publishing House.]

Иванова, Миглена, Мила Сантова, Ива Станоева (сьст и ред.) [Ivanova, Miglena, Mila Santova and Iva Stanoeva (eds.)]

2006 Брегът - морето - Европа. Сборник с материали от Международната науина конферениия „Брегът, 
морето и Европа. Модели на интеркултурна комуникачия”. София: АИ „Проф. Марин Аринов”. [Littoral-Sea-Europe: Collection of Materials from the International Scientific Conference "Littoral, Sea and Europe. Models of Intercultural Communication". Sofia: Academic Publishing House "M. Drinov".]

Аозанова, Галина [Lozanova, Galina]

2008 Сътворението в устната традищия на българите мюсюлмани. София: АИ „Проф. Марин Аринов". [The Creation in the Oral Bulgarian Muslim Tradition. Sofia: Academic Publishing House "M. Drinov".]

Матеева, Ваня [Mateeva, Vanya]

2006 Гагаузите - още един поглед. София: АИ „Проф. Марин Аринов” [Gagauz People - One View More. Sofia: Academic Publishing House "M. Drinov".]

Миков, Аюбомир [Mikov, Lyubomir]

2005 Изкуството на хетеродоксните мюсюлмани в Бъмгария (XVI-XX век). Бекташи и къзъ ббаши/алевии. София: АИ „Марин Аринов”. [The Art of Heterodox Muslims in Bulgaria (XVI-XX century: Bektaşi and Kızılbaş/Alevi. Sofia: Academic Publishing House "M. Drinov".]

2006 (съст.) Култова архитектура и изкуство в Североизточна България (XV-XX век). София, АИ „Проф. Марин Аринов”. [(ed.) Cult Architecture and Art in in North-Eastern Bulgaria (XVXX century). Sofia: Academic Publishing House "M. Drinov".]

Мицева, Евгения [Mitseva, Evgeniya]

2001 Армениите в България - култура и иденичност. София: МЦПМКВ. [Armenians in Bulgaria Culture and Identity. Sofia: International Center for Minority Problems and Intercultural Interaction.]

2005 (съст.) Пространства на Аругостта. София: АИ „Марин Аринов”. [(ed.) Spaces of Otherness. Sofia: Academic Publishing House "M. Drinov".]

Общности и култура

2003 Помагало по етнология и фолклористика. - Пловдив, Пловдивско университетско издателство „Паисий Хилендарски”. Пцовдив: Пцовдивско университетско издателство. [Communities and Culture: Manual in Ethnology and Folklore Studies. Plovdiv: Plovdiv University Publishing House.]

Пейчева, Аозанка. [Pejčeva, Lozanka]

1999 Aушата плаче - песен излиз. Ромките музиканти в Бълария и тяхната музика. София: ТерАРТ. [The Soul Weeps - A song Comes Out: The Roma Musicians in Bulgaria and their Music. Sofia: TerART.]

2008 Между Cелото и Вселената: старата фолклорна музика от България в новите времена. София: АИ „Проф. Марин Аринов”. [Between the Village and the Universe: The Old Folk Music from Bulgaria in Modern Times. Sofia: Academic Publishing House "M. Drinov".]

Пейчева, Аозанка, Венцислав Аимов (съст., ред.) [Pejcheva, Lozanka and Ventsislav Dimov (eds.)] 2005 Музика, роми, медии. София: „Звездан”. [Music, Roma People, Media. Sofia: “Zvezdan”.]

Пенчев, ВАадимир [Penčev, Vladimir]

2001 Паралакс в огледалото, или за миграчионните общности в чуждоетнична среда (Чехи и Словауи в България, българи в Чехия). София. [Paralax in the Mirror, or The Migration Communities in Alien Ethnic Milieu (Czechs and Slovacs in Bulgaria, Bulgarians in Czech Republic). Sofia.]

Пенчев, Владимир, Наталия Рашкова (сьст. и рел.) [Penčev, Vladimir and Natalia Rashkova (eds.)] 2005 Българи в Словакия. Етнокултурни характеристики и взаимодействия. Теренни изследвания. София: АИ „Марин Аринов”. [Bulgarians in Slovakia: Ethnocultural Characteristics and Interactions: Field Studies. Sofia: Academic Publishing House "M. Drinov".]

Пенчев, Владимир, Ева Крековичова (съст.) [Penchev, Vladimir and Eva Krekovichova (eds.)] 2006 Bulhari na Slovensku - etnokultúrné charakteristiky a súvislosti. Bratislava: Veda. [Bulgarians in Slovakia: Ethno-cultural Characteristics and Interactions. Bratislava: Veda.] 
Проблеми на българския фолклор

2005 Т. 10. Фолклор - идентичност - сввременност. София: АИ „Марин Аринов”. [Problems of Bulgarian Folklore. Vol. 10: Folklore - Identity - Modernity. Sofia: Academic Publishing House “M. Drinov".]

Сантова, Мима [Santova, Mila]

2001 Култура и традиция на малкия град. София: АИ „Проф. Марин Аринов”. [Culture and Traditions in a Small Town. Sofia: Academic Publishing House "M. Drinov".]

Сантова, Мила, Ива Станоева (съст.) [Santova, Mila and Iva Stanoeva (eds.)]

2002 Северозападна България: обиности, традичии, иденичност. София: АИ „Проф. М. Аринов”. [North-Western Bulgaria: Communities, Traditions, Identities. Sofia: Academic Publishing House "M. Drinov".]

Сантова, Мила, Мариано Паванело (съст.) [Santova, Mila and Mariano Pavanello (eds.)]

2006 България-Италия. Аебати, локални култури, традиции. София: АИ „Проф. Марин Аринов”. [Bulgaria - Italia. Dibattiti, culture locali, tradizioni / Bulgaria - Italy: Debates, Local Cultures, Traditions. Sofia: Academic Publishing House "M. Drinov".]

Сантова, Мила, Ива Станоева, Миглена Иванова (съст и ред.) [Santova, Mila, Iva Stanoeva and Miglena Ivanova (eds.)]

2006 Брегът - морето - Европа. Сборник с материали от Международната научна конференция „Брегът, морето и Eвропа. Модели на интеркултурна комуникачия”. София: АИ „Проф. Марин Аринов”. [Coast - Sea - Europe: Collected Volume of Materials from the International Scientific Conference "Coast, Sea and Europe: Patterns of Intercultural Communication". Sofia: Academic Publishing House "M. Drinov".]

Станоев, Станой [Stanoev, Stanoy]

2005 Вицът и неговите послания София: АИ „Марин Аринов”. [The Joke and Its Messages. Sofia: Academic Publishing House "M. Drinov".]

Фолклорната култура и човекът

2002 Помагало по фолклористика и етнография. Пловдив, П оовдивско университетско издателство „Паисий Хилендарски”. Пловдив: Пловдивско университетско издателство. [Folk Culture and Man: Manual in Folklore Studies and Ethnography. Plovdiv: Plovdiv University Publishing House. ]

\section{ETNOLOŠKE IDEJE IN PRISTOPI V SODOBNI BOLGARSKI FOLKLORISTIKI}

$V$ bolgarskem znanstvenem prostoru je bilo etnološko znanje samostojno institucionalizirano šele v 90. letih prejšnjega stoletja. Pomemben prispevek, da je etnologija dosegla samostojnost kot znanstvena in pedagoška disciplina v visokem izobraževanju, pripada bolgarski folkloristiki, predvsem folkloristu Todorju Iv. Živkovu.

$V$ 70. letih 20. stoletja je folkloristika v Bolgariji presegla okvire filoloških interpretacij folklore in $v$ zadnjih desetletjih prejšnjega stoletja postala vodilna šola nacionalnih humanističnih raziskav. Folklora je obravnavana kot vrsta kulturnega sistema, kompleksna enovitost kulturnih dejavnosti in kombinacija kulturnih vrednot, ki nastajajo nezavedno in se v času prenašajo kot podedovana kulturna informacija.

Ljudska kultura je interpretirana kot posrednik med posameznikovim in skupinskim mišljenjem, med etničnim in interetničnim, med estetskim in ne-estetskim, med vsakdanjim 
in prazničnim, svetim in posvetnim itn. Predmet interpretacije so strukturni, genetični in regionalni vidiki "ljudskih" tekstov. Folklora je tudi poslej interpretirana kot vrsta mišljenja, izražanja, komunikacije in samo-uresničitve, kot človeška kulturna nuja, tudi $v$ 21. stoletju.

Na začetku 90. let je s pomočjo univerzitetnih predavateljev in raziskovalcev iz različnih inštitutov Bolgarske akademije znanost, večinoma pa iz Inštituta za folkloro, Todor Živkov spodbudil in vpeljal etnologijo kot predmet študija na visokošolski ravni. V knjigi Etnični sindrom se je zavzel za neogibno diferenciacijo studijskega predmeta in ponudil podroben študijski program za enovito etnološko izobraževanje, utemeljeno na podlagi filologije in bližnjih družbenih ved. Predmetnik je bil postavljen na Univerzi P. Hilendarskega v Plovdivu, na Jugozahodni univerzi Neofit Rilski v Blagoevgradu in na Slavistični univerzi v Sofiji. Njegove zamisli so temelj za uvedbo etnologije in antropologije v drugih visokih šolah $v$ Bolgariji.

Izdane so bile prve publikacije,v katerih je bila etnologija teoretično utemeljena kot sintetično znanje o človeških skupnostih. Izvedenci iz Inštituta za folkloro so sodelovali v znanstveni razpravi z lastnimi raziskavami, priročniki itn. Revija Bolgarska folklora je začela objavljati razdelek Alma Mater s študijami, povezanimi z različnimi etnološkimi disciplinami.

Danes raziskovalci iz Inštituta za folkloro sodelujejo v izobraževanju specialistov v etnologiji in antropologiji na osmih visokih šolah. Posebej je pomemben bolgarsko-italijanski magistrski program Antropološke študije Sredozemlja in Balkana (Italija-Bolgarija), tj. sodelujoča aktivnost Inštituta za folkloro, Univerze La Sapienza v Rimu in Fakultete za klasično in novo fllologijo (Oddelek za romanistiko sofijske Univerze Sv. Klimenta Ohridskega, Sofija).

Po letu 1990 se je bolgarska folkloristika razvijala v več smereh: s spremembo pogleda na predmet raziskav (kombinacija mikro- in makroanaliz na različnih ravneh); zanimanjem za nove predmete; z interdisciplinarnim študijem. Glavni raziskovalni poudarki se nanašajo na vprašanja kulturne identitete in medkulturnih stikov $v$ nacionalnem in evropskem kontekstu, na kulturno politiko $v$ sodobnosti, na teoretične in uporabne vidike nesnovne kulturne dedišcine. Cilj je interdisciplinarni prijem $k$ tem problemom (z metodami folkloristike, kulturne antropologije, etnologije, etnomuzikologije, sociologije idr. ved). Teoretski seminarji so izjemnega metodološkega pomena, saj obravnavajo splošne in posebne probleme folklorističnega, etnološkega in antropološkega znanja, zgodovino predmeta teh disciplin in njihovo razmerje s sorodnimi vedami.

Raziskovalni interes $v$ Bolgariji se je po letu 1990 usmeril $k$ mestom in urbani etnologiji in antropologiji. Teme, o katerih se mdr. razpravlja, so: vloga urbanih institucij pri izobraževanju in posredovanju folklore; spreminjanje oblik regionalne ljudske kulture v kulturno dedišcino mest; "rabe" folklore v ustvarjanju nacionalne naracije in podoba Bolgarije kot dežele kulturne raznovrstnosti in dela evropskega kulturnega prostora. Inštitut je pomembno prispeval k raziskavam tradicionalnih in sodobnih kultur različnega značaja-lokalnih, 
regionalnih, nacionalnih, transnacionalnih, etničnih, verskih idr. Predmet zanimanja so subkulture mladih, kulture skupin neenakopravnega družbenega položaja. Folkloristika uspešno interpretira sodobne subkulturne pojave in procese - $v$ glasbi, ritualih in šegah, ustni umetnosti. Pomemben napredek je bil dosežen tudi na področju uporabne etnologije.

Assist. Prof. Dr. Valentina Ganeva-Raycheva, Institute of Ethnology and Folklore Studies with Ethnographic Museum, Bulgarian Academy of Sciences, valrai@abv.bg 